OPEN ACCESS

Edited by:

Rosa M. Rivero,

Centro de Edafología y Biología Aplicada del Segura (CSIC), Spain

Reviewed by:

Mirza Hasanuzzaman, Sher-e-Bangla Agricultural University, Bangladesh

Mathias Neumann Andersen, Aarhus University, Denmark

${ }^{*}$ Correspondence: Jiwang Zhang jwzhang@sdau.edu.cn

Specialty section: This article was submitted to Plant Abiotic Stress, a section of the journal Frontiers in Plant Science

Received: 10 January 2017 Accepted: 27 June 2017 Published: 11 July 2017

Citation:

Ren B, Dong S, Zhao B, Liu P and Zhang J (2017) Responses of Nitrogen Metabolism, Uptake and Translocation of Maize to Waterlogging at Different Growth

Stages. Front. Plant Sci. 8:1216. doi: 10.3389/fpls.2017.01216

\section{Responses of Nitrogen Metabolism, Uptake and Translocation of Maize to Waterlogging at Different Growth Stages}

\author{
Baizhao Ren, Shuting Dong, Bin Zhao, Peng Liu and Jiwang Zhang* \\ State Key Laboratory of Crop Biology and College of Agronomy, Shandong Agricultural University, Taian, China
}

We performed a field experiment using the maize hybrids DengHai605 (DH605) and ZhengDan958 (ZD958) to study nitrogen uptake and translocation, key enzyme activities of nitrogen metabolism in response to waterlogging at the third leaf stage (V3), the sixth leaf stage (V6), and the 10th day after the tasseling stage (10VT). Results showed that $\mathrm{N}$ accumulation amount was significantly reduced after waterlogging, most greatly in the V3 waterlogging treatment (V3-W), with decreases of 41 and 37\% in DH605 and ZD958, respectively. $\mathrm{N}$ accumulation in each organ and $\mathrm{N}$ allocation proportions in grains decreased significantly after waterlogging, whereas $\mathrm{N}$ allocation proportions increased in stem and leaf. The reduction in stem and leaf $\mathrm{N}$ accumulation after waterlogging was mainly caused by a decrease in dry matter accumulation, and a reduction in $\mathrm{N}$ translocation from stems and leaves to grains after waterlogging. Additionally, waterlogging decreased the activity of key $\mathrm{N}$ metabolism enzymes (nitrate reductase, glutamine, glutamate synthase, and glutamate dehydrogenase), and the most significant reduction in V3-W with a decrease of $59,46,35$, and $26 \%$ for $\mathrm{DH} 605$, and 60, 53, 31, and 25 for ZD958, respectively. Waterlogging disrupted $\mathrm{N}$ metabolism, hindered $\mathrm{N}$ absorption and transportation, and decreased maize yield.

Keywords: maize (Zea mays L.), waterlogging in the field, $\mathrm{N}$ metabolism, $\mathrm{N}$ uptake and translocation, grain yield

\section{INTRODUCTION}

Waterlogging is one of major abiotic stresses in crop production. Globally, it is estimated that $12 \%$ of cropping areas are affected by waterlogging (Sergey, 2011). By influencing crop growth and development (Kozlowski, 1997; Jackson and Campbell, 2006), waterlogging significantly reduces grain yield. In the Huanghuaihai Plain, most rainfall takes place during maize growth periods; thus, waterlogging is a frequent natural disturbance to maize production (Chi and Zhou, 2006) which inhibits its growth and development (Ren et al., 2014a). In waterlogged soil, anaerobic respiration is enhanced, a large number of harmful substances, such as hydrogen sulfide $\left(\mathrm{H}_{2} \mathrm{~S}\right)$ and ferrous sulfide ( $\mathrm{FeS}$ ) accumulate, and the rhizosphere environment deteriorates leading to inhibited absorption of mineral ions and beneficial trace elements, and eventually resulting in disruption of root growth and development (Ashraf and Rehman, 1999; Przywara and Stcdaniewski, 1999). The restriction of root growth, induced by waterlogging, limits the absorption of nitrogen $(\mathrm{N})$ fertilizer absorption, disrupting $\mathrm{N}$ uptake, transportation, and distribution in each organ, eventually leading to a reduction in $\mathrm{N}$ use efficiency (Ren et al., 2016). 
The inhibition of crop growth after waterlogging may be caused by soil oxygen deficit, which inhibits the main metabolism of crops and changes the effectiveness of crop nutrition and soil nutrients (Lawlor, 2002; Milroy et al., 2009; Ren et al., 2016). N metabolism is a basic physiological process in which related enzymes play an important role in plant resistance to adverse environmental conditions (Ramanjulu and Sudhakar, 1997). N metabolism has been shown to contribute cellular acclimation to low oxygen stress in plants (Bailey-Serres et al., 2012). N deficiency may be induced by the low redox potential in waterlogged soils that promotes denitrification of nitrate $\left(\mathrm{NO}_{3}{ }^{-}\right)$ (Limami et al., 2014). Nitrate reductase (NR), glutamine (GS), glutamate synthase (GOGAT), and glutamate dehydrogenase $(\mathrm{GDH})$ are key enzymes in $\mathrm{N}$ metabolism, whose activities have been used as representative biochemical markers to evaluate $\mathrm{N}$ status. NR is a key enzyme which adjusts the $\mathrm{N}$ assimilation and metabolism process, and is sensitive to changes in environmental conditions (Kaiser and Huber, 1994). The reduction of NR activity in leaves of waterlogged plants is due to a rapid depletion of $\mathrm{NO}_{3}{ }^{-}$and oxygen under anaerobic conditions (Sung and Sun, 1990; Hoff et al., 1992). As a result, volatilization and loss of $\mathrm{NO}_{3}{ }^{-}$are promoted through denitrification. Under water stress, NR activity can be suppressed, limiting the reduction of $\mathrm{NO}_{3}{ }^{-}$and the assimilation of $\mathrm{NH}_{4}{ }^{+}$, leading to the generation of $\mathrm{NH}_{4}{ }^{+}$and a short supply of alpha ketone glutaric acid; thus activities of GS and GOGAT are reduced, resulting in the accumulation of $\mathrm{NH}_{4}{ }^{+}$In recent years, much research has been conducted on the responses of NR, GS, GOGAT, and GDH activities in crops to various environmental stresses (Eva et al., 2011; Robredo et al., 2011) and cultivation methods (Debouba et al., 2006; Monreal et al., 2007). However, very little attention has been given to the effects of waterlogging on $\mathrm{N}$ metabolism, $\mathrm{N}$ uptake, and translocation in maize. To examine the responses of $\mathrm{N}$ metabolism, uptake and translocation of maize to waterlogging at different stages, we performed a field experiment in which we determined the effects of waterlogging at the third leaf stage, the sixth leaf stage, and the 10th day after the tasseling stage on $\mathrm{N}$ accumulation and translation, the activities of $\mathrm{N}$ metabolism enzymes, and yield.

\section{MATERIALS AND METHODS}

\section{Experimental Location}

A field experiment was conducted at the State Key Laboratory of Crop Biology and the experimental farm of Shandong Agricultural University, China $\left(36^{\circ} 10^{\prime} \mathrm{N}, 117^{\circ} 04^{\prime} \mathrm{E}, 151 \mathrm{~m}\right.$ altitude) in 2012 and 2013. The region has a temperate continental monsoon climate. The effective accumulated

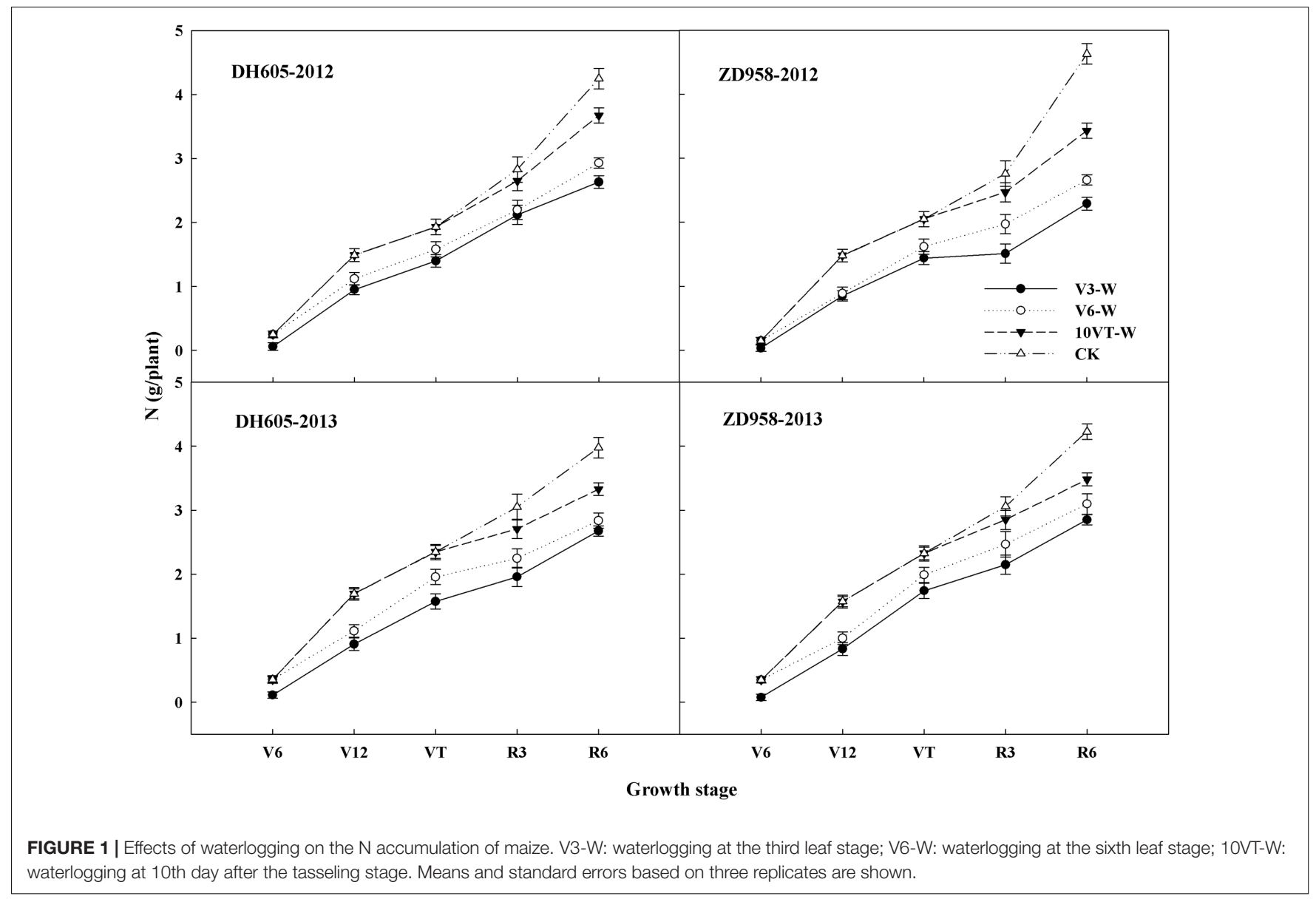


temperatures of maize growth periods in 2012 and 2013 were $1710.9^{\circ} \mathrm{C} \mathrm{d}$ and $1740.5^{\circ} \mathrm{C} \mathrm{d}$, respectively. The mean total precipitation values during maize growth periods in 2012 and 2013 were $350.0 \mathrm{~mm}$ and $348.5 \mathrm{~mm}$, respectively. The soil type was sandy loam, and soil $\mathrm{pH}$ was 8.25 (Cambisols; FAO/EC/ISRIC 2003). The plowed soil $(0-20 \mathrm{~cm})$ before the experiment contained $10.2 \mathrm{~g} \mathrm{~kg}^{-1}$ of organic matter, with total mounts of $\mathrm{N}$ : $0.9 \mathrm{~g} \mathrm{~kg}^{-1}$, rapidly available phosphorus (P): $50.3 \mathrm{mg} \mathrm{kg}^{-1}$, and rapidly available potassium (K): $85.4 \mathrm{mg} \mathrm{kg}^{-1}$.

\section{Experimental Design}

Each plot was $4 \mathrm{~m} \times 4 \mathrm{~m}$ and separated by $4 \mathrm{~m} \times 2.3 \mathrm{~m}$ polyvinyl chloride (PVC) boards as water barriers. Every PVC board was buried $2.0 \mathrm{~m}$ below the surface, with remaining $0.3 \mathrm{~m}$ aboveground. Experimental treatments matched different waterlogging stages: the third leaf stage (V3; V3-W), the sixth leaf stage (V6; V6-W), and the 10th day after the tasseling stage (10VT; 10VT-W), and no waterlogging (CK). In the CK, soil moisture was kept optimum during the whole growth period. We selected the maize hybrids DengHai605 (DH605) and ZhengDan958 (ZD958) as experimental materials, because they are the most commonly planted varieties in China. Maize was sown on June 16 in both years, at a plant density of 67,500 plants $\mathrm{ha}^{-1}$. The water in waterlogged pools was maintained at $2-3 \mathrm{~cm}$ above the soil surface for $6 \mathrm{~d}$. Each treatment was replicated three times, in a completely randomized block design. $300 \mathrm{~kg} \mathrm{ha}^{-1}$ urea (N 46\%), $857 \mathrm{~kg} \mathrm{ha}^{-1}$ calcium superphosphate $\left(\mathrm{P}_{2} \mathrm{O}_{5} 17 \%\right)$, and $400 \mathrm{~kg} \mathrm{ha}^{-1}$ muriate of potash $\left(\mathrm{K}_{2} \mathrm{O} 60 \%\right)$ were applied. Prior to seeding, $\mathrm{P}, \mathrm{K}$ compound fertilizer was applied one-off to prepare the soil for sowing, $40 \% \mathrm{~N}$ compound fertilizer was applied at V6, and 60\% N compound fertilizer was applied at V12. Disease, weeds, and pests were well controlled in each treatment.

\section{Dry Matter and N Amount}

Five representative plant samples were obtained from each plot at V6, the twelfth leaf stage (V12), the tasseling stage (VT), the milk stage (R3), and the physiological maturity stage (R6), according to Ritchie and Hanway (1982). Samples were preserved after being separated into stem and leaf at V6, V12, and VT, and separated into stem, leaf, and ear at R3 and R6. Samples were dried at $80^{\circ} \mathrm{C}$ in a force-draft oven (DHG-9420A, Bilon Instruments Co., Ltd, Shanghai, China) to a constant weight and weighed separately.

TABLE 1 | Effect of waterlogging on $\mathrm{N}$ accumulation (g plant ${ }^{-1}$ ) and distribution (\%) of maize at maturity stage.

\begin{tabular}{|c|c|c|c|c|c|c|c|c|c|c|c|c|}
\hline \multirow{2}{*}{$\begin{array}{l}\text { Year } \\
(Y)\end{array}$} & \multirow{2}{*}{$\begin{array}{c}\text { Hybrid } \\
\text { (H) }\end{array}$} & \multirow{2}{*}{$\begin{array}{c}\text { Treatment } \\
\text { (T) }\end{array}$} & \multirow{2}{*}{$\begin{array}{c}\text { Total } \\
\text { accumulation } \\
\left(\text { g plant }^{-1}\right)\end{array}$} & \multicolumn{2}{|l|}{ Stem } & \multicolumn{2}{|l|}{ Leaf } & \multicolumn{2}{|l|}{ Cob } & \multicolumn{2}{|l|}{ Grain } & \multirow[t]{2}{*}{ NHI } \\
\hline & & & & g plant $^{-1}$ & $\%$ & g plant ${ }^{-1}$ & $\%$ & g plant ${ }^{-1}$ & $\%$ & g plant ${ }^{-1}$ & $\%$ & \\
\hline \multirow[t]{8}{*}{2012} & DH605 & V3-W & $2.02 \mathrm{c}$ & $0.26 \mathrm{c}$ & 12.8 & $0.34 b$ & 16.7 & $0.06 b$ & 3.0 & $1.36 c$ & 67.6 & $0.68 \mathrm{c}$ \\
\hline & & V6-W & $2.16 \mathrm{c}$ & $0.27 b c$ & 12.5 & $0.35 b$ & 16.3 & $0.06 b$ & 2.9 & $1.48 \mathrm{c}$ & 68.2 & $0.68 \mathrm{c}$ \\
\hline & & 10VT-W & $2.93 b$ & $0.30 \mathrm{ab}$ & 10.2 & $0.40 a$ & 13.5 & $0.09 a b$ & 3.2 & $2.14 b$ & 73.2 & $0.73 b$ \\
\hline & & CK & $4.08 a$ & $0.32 a$ & 7.8 & $0.42 a$ & 10.4 & $0.13 a$ & 3.1 & $3.22 a$ & 78.7 & $0.79 a$ \\
\hline & ZD958 & V3-W & $2.22 \mathrm{c}$ & $0.20 \mathrm{c}$ & 8.9 & $0.43 c$ & 19.4 & $0.13 b$ & 5.7 & $1.46 \mathrm{c}$ & 66 & $0.66 c$ \\
\hline & & V6-W & $2.34 \mathrm{c}$ & $0.26 b$ & 11.1 & $0.45 b c$ & 19.5 & $0.14 b$ & 5.9 & $1.48 c$ & 63.6 & $0.64 \mathrm{c}$ \\
\hline & & 10VT-W & $3.24 b$ & $0.27 a b$ & 8.3 & $0.47 b$ & 14.5 & $0.19 a$ & 5.7 & $2.32 b$ & 71.5 & $0.72 b$ \\
\hline & & CK & $3.88 a$ & $0.29 a$ & 7.4 & $0.53 a$ & 13.7 & $0.21 a$ & 5.4 & $2.85 a$ & 73.5 & $0.74 a$ \\
\hline \multirow[t]{16}{*}{2013} & DH605 & V3-W & $2.85 c$ & $0.30 c$ & 10.5 & $0.43 b$ & 15.1 & $0.12 b$ & 4.2 & $2.00 d$ & 70.2 & $0.70 \mathrm{~b}$ \\
\hline & & V6-W & $3.09 b c$ & $0.32 b c$ & 10.4 & $0.46 \mathrm{~b}$ & 15 & $0.12 b$ & 4.0 & $2.19 c$ & 70.9 & $0.71 b$ \\
\hline & & 10VT-W & $3.48 b$ & $0.33 b$ & 9.6 & $0.55 a$ & 15.7 & $0.13 a b$ & 3.8 & $2.47 \mathrm{~b}$ & 71.0 & $0.71 b$ \\
\hline & & CK & $4.22 a$ & $0.40 a$ & 9.4 & $0.58 a$ & 13.9 & $0.14 \mathrm{a}$ & 3.4 & $3.10 a$ & 73.4 & $0.73 a$ \\
\hline & ZD958 & V3-W & $2.67 \mathrm{c}$ & $0.27 b$ & 10.2 & $0.48 b$ & 18.0 & $0.15 b$ & 6.4 & $1.78 \mathrm{c}$ & 66.7 & $0.67 b$ \\
\hline & & V6-W & $2.83 \mathrm{bc}$ & $0.30 \mathrm{~b}$ & 10.5 & $0.49 a b$ & 17.2 & $0.15 b$ & 5.3 & $1.89 c$ & 66.8 & $0.67 b$ \\
\hline & & 10VT-W & 3.32ab & $0.30 \mathrm{~b}$ & 9.1 & $0.50 \mathrm{ab}$ & 15.1 & $0.17 \mathrm{~b}$ & 5.1 & $2.24 b$ & 67.5 & $0.67 b$ \\
\hline & & CK & $3.97 a$ & $0.35 a$ & 8.8 & $0.51 a$ & 12.9 & $0.20 \mathrm{a}$ & 5.1 & $2.90 a$ & 73.1 & $0.73 a$ \\
\hline & ANOVA & & & & & & & & & & & \\
\hline & Y & & $* *$ & $* *$ & & $*$ & & $*$ & & $*$ & & NS \\
\hline & $\mathrm{H}$ & & NS & $* *$ & & NS & & $* *$ & & NS & & $*$ \\
\hline & $\mathrm{T}$ & & $* *$ & $* *$ & & NS & & $* *$ & & $* *$ & & $*$ \\
\hline & $\mathrm{Y} \times \mathrm{H}$ & & $*$ & NS & & $*$ & & $*$ & & NS & & NS \\
\hline & $\mathrm{Y} \times \mathrm{T}$ & & NS & NS & & NS & & NS & & NS & & NS \\
\hline & $\mathrm{H} \times \mathrm{T}$ & & NS & NS & & NS & & NS & & NS & & NS \\
\hline & $\mathrm{Y} \times \mathrm{H} \times \mathrm{T}$ & & NS & NS & & NS & & NS & & NS & & NS \\
\hline
\end{tabular}

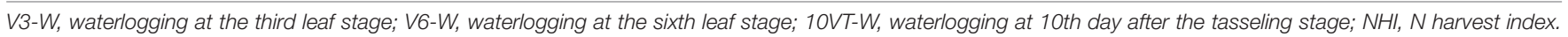

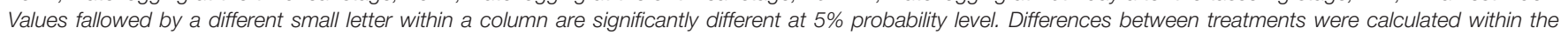
hybrids for each particular year. NS, Not significant. *Significant at the 0.05 probability level. **Significant at the 0.01 probability level. 
Total $\mathrm{N}$ was measured using the Kjeldahl method (Hibbard, 2002):

$$
\begin{aligned}
& \text { Nitrogen harvest index (NHI, \%) } \\
& \quad=\text { grain } \mathrm{N} \text { amount/total } \mathrm{N} \text { amount of plant } \\
& \text { Harvest index (HI, \%) } \\
& \quad=\text { grain dry weight/total dry weight of plant }
\end{aligned}
$$

\section{NR Activity}

The functional leaves from five plant samples were obtained from the center of each plot at the next day after the end of waterlogging treatments. NR activity was estimated using the method of Aslam et al. (2001). The samples (0.5 g) were placed in $10 \mathrm{~mL}$ of incubation medium, which was $0.1 \mathrm{M}$ potassium phosphate buffer ( $\mathrm{pH} 7.5$ ) containing $0.1 \mathrm{M} \mathrm{KNO}_{3}$ with $1 \%(\mathrm{v} / \mathrm{v})$ propanol. Prior to the assay, the buffer solution was purged with $\mathrm{N}_{2}$ gas for $30 \mathrm{~min}$ to remove dissolved oxygen, and samples then were vacuum-infiltrated (two times), and incubated in a water bath at $30^{\circ} \mathrm{C}$ for $30 \mathrm{~min}$ in the dark. $1 \mathrm{~mL}$ sample was withdrawn for the color reaction, and initiated by adding $2 \mathrm{~mL}$ aminobenzenesulfonic acid and $2 \mathrm{~mL}$ a-naphthylamine. After 20 min of incubation, the amount of nitrite $\left(\mathrm{NO}_{2}{ }^{-}\right)$ was determined by absorbance at $520 \mathrm{~nm}$ using a standard curve.

\section{GS, GOGAT, and GDH Activities}

The functional leaves from five plant samples were obtained from the center of each plot at the next day after the end of waterlogging treatments. To extract enzymes, $0.5 \mathrm{~g}$ of leaf tissue was homogenized with $10 \mathrm{mM}$ Tris- $\mathrm{HCl}$ buffer (pH 7.6, containing $1 \mathrm{mM} \mathrm{MgCl}_{2}, 1 \mathrm{mM}$ EDTA, and $1 \mathrm{mM}$ 2-mercaptoethanol) in a chilled pestle and mortar. The homogenate was centrifuged at $15000 \times g$ for $30 \mathrm{~min}$ at $4^{\circ} \mathrm{C}$. The supernatant was used to determine enzyme activities.

Glutamine was assayed according to Mohanty and Fletcher (1980). The reaction mixture contained in a final volume of $1 \mathrm{~mL}, 80 \mu \mathrm{mol}$ Tris-HCl buffer, $40 \mu \mathrm{mol}$ L-glutamic acid,

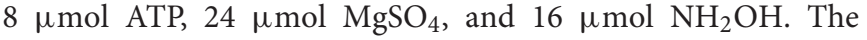
final $\mathrm{pH}$ was 8.0. The reaction was initiated by the addition of the enzyme extract. After incubation for $30 \mathrm{~min}$ at $30^{\circ} \mathrm{C}$, the reaction was stopped by adding $2 \mathrm{~mL} \mathrm{2.5 \% (w/v)} \mathrm{FeCl}_{3}$ and $5 \%$ $(\mathrm{w} / \mathrm{v})$ trichloroacetic acid in $1.5 \mathrm{M} \mathrm{HCl}$. After centrifugation at $3000 \times g$ for $10 \mathrm{~min}$, the absorbance of the supernatant was read at $540 \mathrm{~nm}$. GS activity was expressed as $1 \mu \mathrm{mol}$ L-glutamate $\gamma$-monohydroxamate (GHA) formed $\mathrm{g}^{-1} \mathrm{FW} \mathrm{h}^{-1}$, with $\mu \mathrm{mol}$ $\mathrm{GHA} \mathrm{g}^{-1} \mathrm{FM} \mathrm{h}^{-1}$ said.

Glutamate synthase activity was measured based on the method described by Singh and Srivastava (1986), in units of $\mu$ mol NADH $\mathrm{g}^{-1} \mathrm{FM} \mathrm{min}^{-1}$. The assay mixture contained $0.4 \mathrm{~mL} 20 \mathrm{mM}$ L-glutamine, $0.05 \mathrm{~mL} 0.1 \mathrm{M}$ 2-oxoglutarate, $0.1 \mathrm{~mL} 10 \mathrm{mM}$ KCI, $0.2 \mathrm{~mL} 3 \mathrm{mM} \mathrm{NADH}$, and $0.5 \mathrm{~mL}$ of the

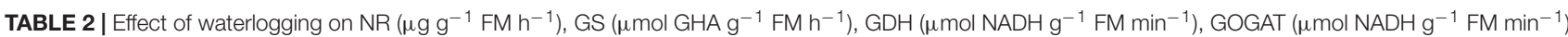
activities of maize (2013).

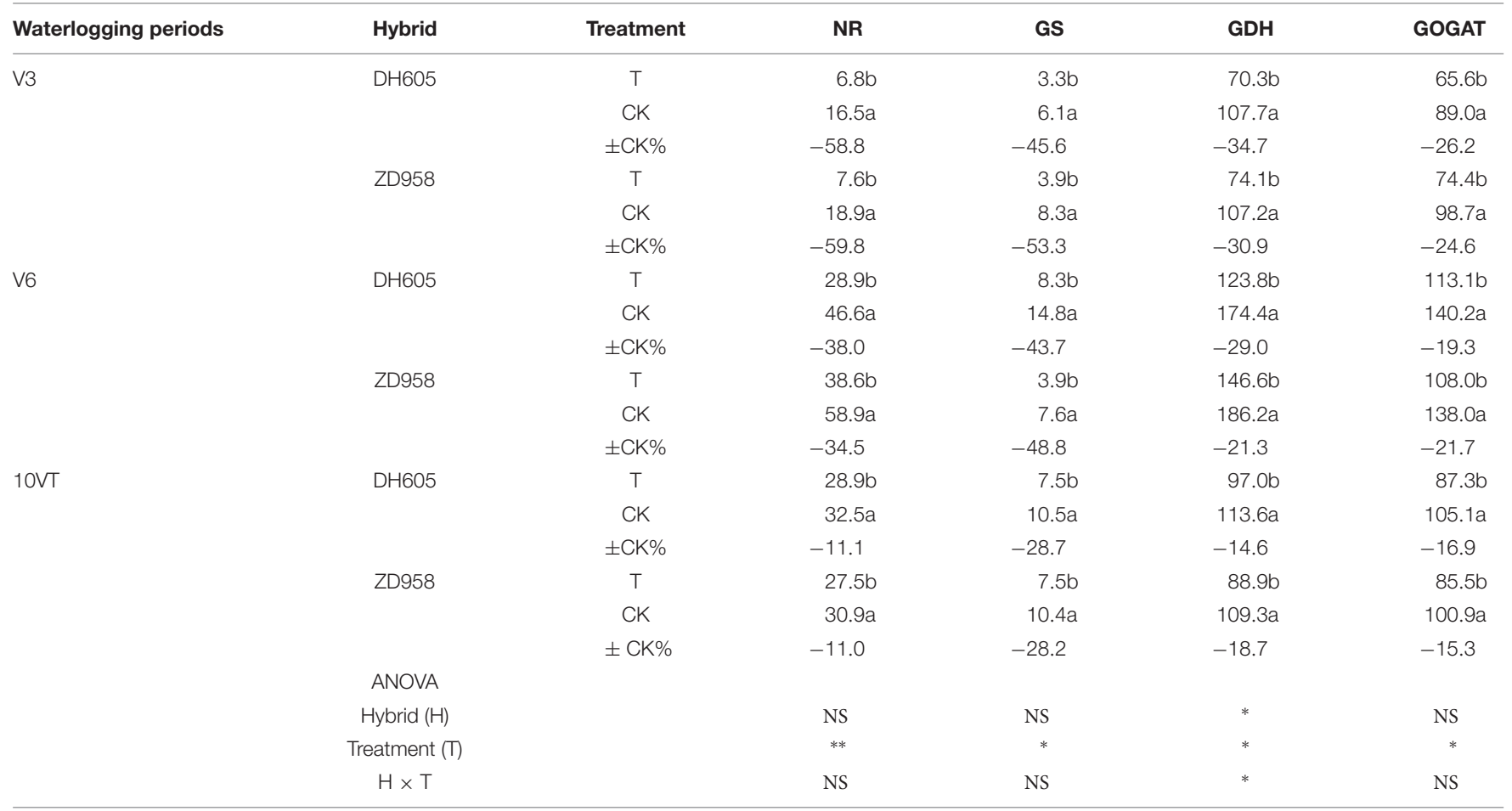

V3-W, waterlogging at the third leaf stage; V6-W, waterlogging at the sixth leaf stage; 10VT-W, waterlogging at 10th day after the tasseling stage; NR, nitrate reductase;

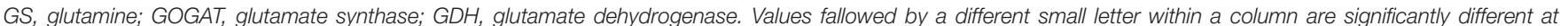

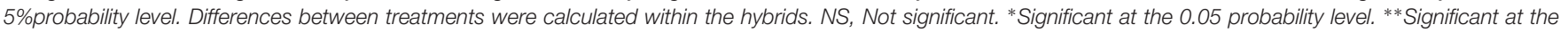
0.01 probability level. 


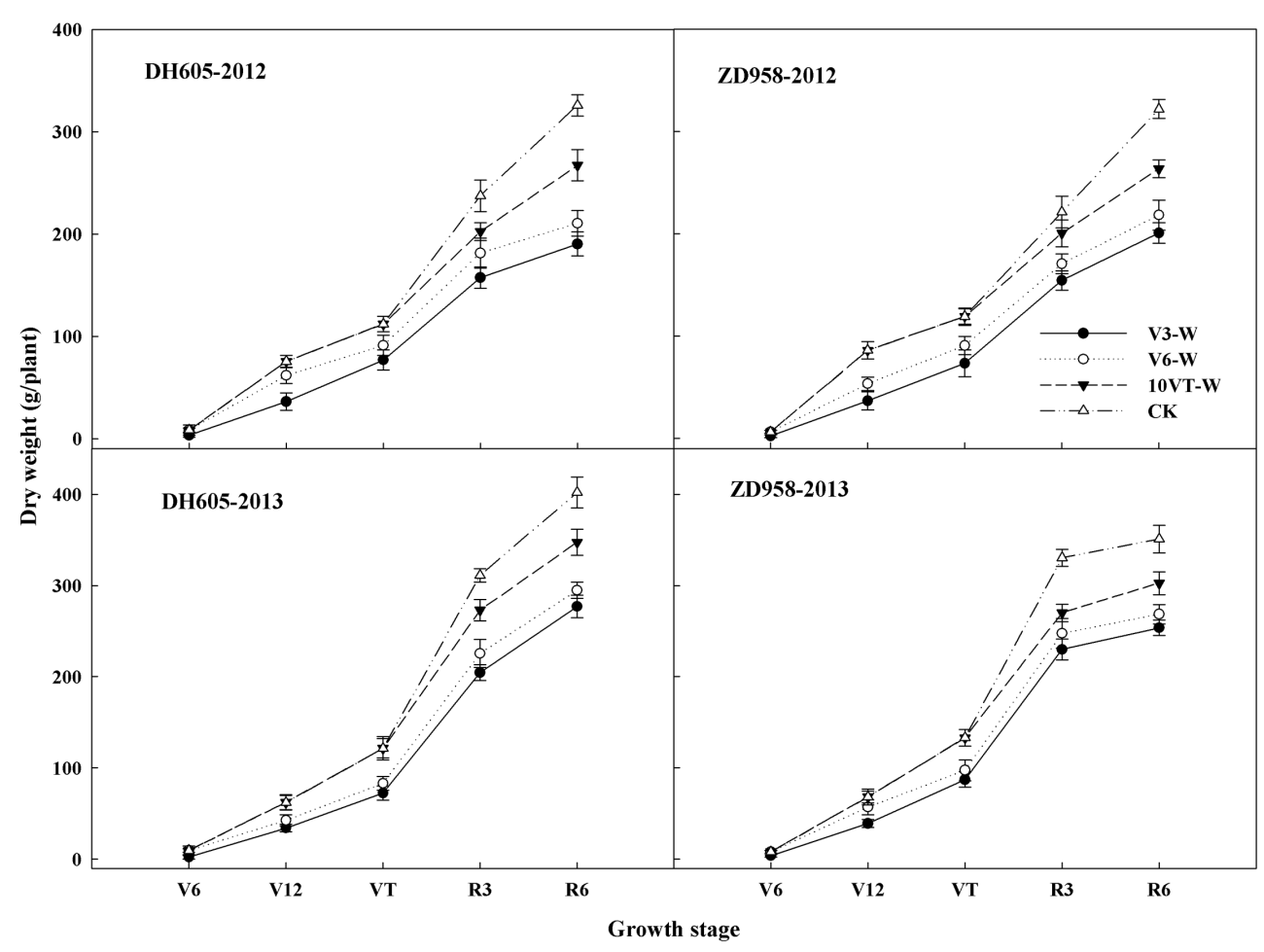

FIGURE 2 | Effects of waterlogging on dry matter accumulation of maize. V3-W: waterlogging at the third leaf stage; V6-W: waterlogging at the sixth leaf stage; 10VT-W: waterlogging at 10th day after the tasseling stage. Means and standard errors based on three replicates are shown.

enzyme extract in a final volume of $3 \mathrm{~mL}$, prepared with $25 \mathrm{mM}$ Tris-HCl buffer ( $\mathrm{pH}$ 7.6). The reaction was initiated by adding L-glutamine immediately following the enzyme preparation. The decrease in absorbance was recorded for $3 \mathrm{~min}$ at $340 \mathrm{~nm}$.

Glutamate dehydrogenase activity was estimated by using the method of Lin and Kao (1996), in unites of $\mu$ mol NADH $\mathrm{g}^{-1} \mathrm{FM} \mathrm{min}{ }^{-1}$. The assay mixture contained $0.3 \mathrm{~mL} 0.1 \mathrm{M}$ 2-oxoglutarate, $0.3 \mathrm{~mL} 1 \mathrm{M} \mathrm{NH}_{4} \mathrm{Cl}, 0.2 \mathrm{~mL} 3 \mathrm{mM} \mathrm{NADH}$ and $1 \mathrm{~mL}$ of the enzyme extract in a final volume of $3 \mathrm{~mL}$, prepared with $0.2 \mathrm{M}$ Tris- $\mathrm{HCl}$ buffer ( $\mathrm{pH} 8.0$ ). The reaction was initiated by adding the enzyme extract. The decrease in absorbance was recorded for $3 \mathrm{~min}$ at $340 \mathrm{~nm}$.

\section{Yield}

At R6, 30 ears harvested from three rows at the center of each plot were used to determine yield and ear traits including length, width, weight, row number, kernels per row, bald tip length, cob weight, and cob width. All kernels were air-dried to determine yield, and grain yield was expressed at 14\% moisture content, according to the standard moisture content of maize for storage or sale is $14 \%$ in China (GB/T 29890-2013).

$$
\begin{aligned}
& \text { Grain yield }\left(\mathrm{kg} \mathrm{ha}^{-1}\right) \\
& =\text { Harvest ear }\left(\text { ears ha }^{-1}\right) \times \text { kernel number per ear } \\
& \quad \times 1000-\text { grain weight }\left(\mathrm{g} 1000 \text { grains }^{-1}\right) / 10^{6} \\
& \quad \times(1-\text { moisture content } \%) /(1-14 \%)
\end{aligned}
$$

\section{Statistical Analysis}

The data were subjected to three-way analysis of variance (ANOVA). Growing season, blocks, and block interactions were included as random effects. Waterlogging treatment and hybrids were included as fixed effects. In case of significant treatment effects, comparison of means was performed by means of LSD at a significance level of 0.05. LSD was used to compare adjacent means arranged in order of magnitude. ANOVA and the LSD test were conducted using the SPSS17.0 software program (Ver. 17.0, SPSS, Chicago, IL, United States). Figures were prepared using a SigmaPlot 10.0 program.

\section{RESULTS}

\section{N Uptake and Translocation}

Waterlogging significantly affected $\mathrm{N}$ uptake and translocation in maize. The V3 stage was most susceptible to waterlogging, followed by V6 and 10VT stages. Waterlogging significantly decreased total $\mathrm{N}$ accumulation in maize, compared to $\mathrm{CK}$. The total $\mathrm{N}$ accumulation levels of DH605 in treatments $\mathrm{V} 3-\mathrm{W}$, V6-W, and 10VT-W were 39, 36, and 19\% lower than that of CK across hybrids and years (Figure 1). There were no significant year $\times$ hybrid $\times$ waterlogging treatment interaction effects on $\mathrm{N}$ accumulation and distribution at the R6 stage (Table 1). The greatest reduction sin stem, leaf, cob, and grain $\mathrm{N}$ accumulation were found in the V3-W treatment at 25, 18, 34, and $46 \%$ 
TABLE 3 | Effect of waterlogging on dry matter accumulation (g plant ${ }^{-1}$ ) and distribution (\%) of maize at maturity stage.

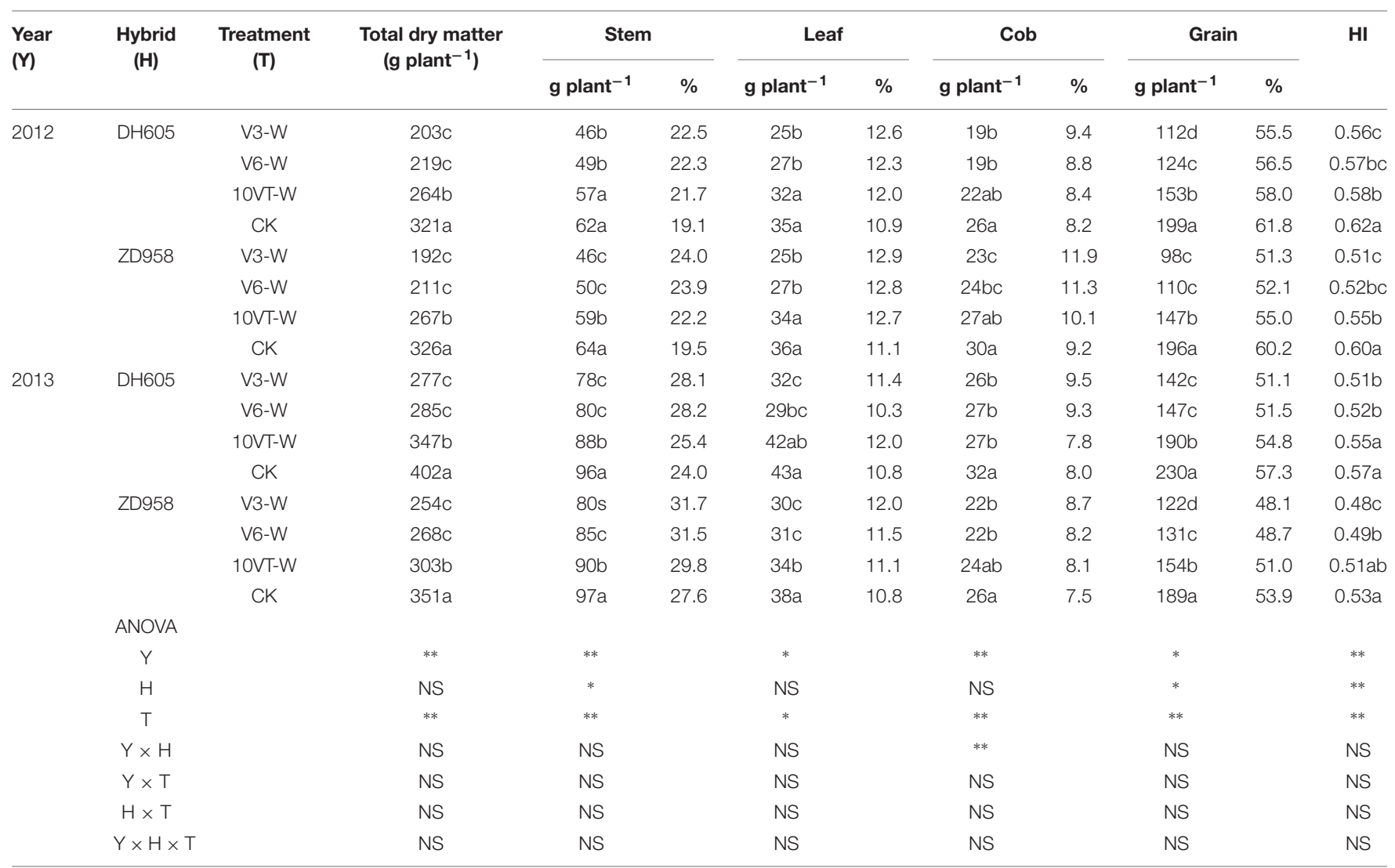

V3-W, waterlogging at the third leaf stage; V6-W, waterlogging at the sixth leaf stage; 10VT-W, waterlogging at 10th day after the tasseling stage; HI, harvest index. Values fallowed by a different small letter within a column are significantly different at $5 \%$ probability level. Differences between treatments were calculated within the hybrids for each particular year. NS, Not significant. * Significant at the 0.05 probability level. **Significant at the 0.01 probability level.

across hybrids and years, compared to those in CK. Additionally, waterlogging increased $\mathrm{N}$ distribution rate in leaf, stem, and cob, whereas grain $\mathrm{N}$ distribution rate decreased significantly after waterlogging, compared to CK. Waterlogging significantly decreased NHI of maize, with the most significant reduction (approximately 10\%) in the $\mathrm{V} 3-\mathrm{W}$ treatment across hybrids and years, compared to that of CK (Table 1).

\section{N Metabolism Enzyme Activity}

Waterlogging significantly decreased the activities of key $\mathrm{N}$ metabolism enzymes, compared to $\mathrm{CK}$, with no significant hybrid $\times$ waterlogging treatment interaction effects (Table 2). The greatest reduction in the activities of NR (approximately 60\%), GS (approximately 50\%), GDH (approximately 33\%), and GOGAT (approximately 26\%) took place when waterlogging occurred at V3, whereas waterlogging at V6 produced activity reductions of $37,47,25$, and $20 \%$, and waterlogging at $10 \mathrm{VT}$ produced activity reductions of $11,29,17$, and $16 \%$ for these key $\mathrm{N}$ metabolism enzymes across hybrids and years.

\section{Dry Matter Accumulation and Distribution}

Effects of waterlogging on dry matter accumulation were similar between the two hybrids (Figure 2). Total dry matter accumulation was significantly reduced by waterlogging at different stages, with the most significant reduction (approximately 34\%) in the V3-W treatment across hybrids and years. There were no significant year $\times$ hybrid $\times$ waterlogging treatment interaction effects on dry matter accumulation or distribution at the R6 stage (Table 3). The greatest reduction in dry matter weight in stem (approximately 22\%), leaf (approximately 27\%), cob (approximately 21\%), and grain (approximately 42\%) occurred in the V3-W treatment. Waterlogging increased dry matter distribution rate in stem, leaf, and cob, whereas that in grain was significantly reduced after waterlogging. Waterlogging also significantly decreased the $\mathrm{HI}$, with the most significant reduction (approximately 11\%) in V3-W across hybrids and years, compared to that of CK (Table 3).

\section{Grain Yield}

Waterlogging resulted in a significant yield reduction in maize (Table 4). The greatest yield reduction (approximately 38\%) occurred in the V3, whereas waterlogging at V6 and 10VT produced yield reductions of 30 and 15\% across hybrids and years, respectively. Waterlogging also decreased grain number per ear and 1000-grain weight, with the most significant 
reduction in the $\mathrm{V} 3-\mathrm{W}$ treatment with decreases of 22 and $16 \%$ across hybrids and years.

\section{DISCUSSION}

$\mathrm{N}$ is a key plant nutrient and signal molecule which controls many aspects of plant metabolism and development (Stitt et al., 2002; Krouk et al., 2010). Previous studies showed that waterlogging significantly affects plant nutrient accumulation and distribution (Iqra and Naveela, 2013). Our study also showed that waterlogging at different stages significantly decreased $\mathrm{N}$ accumulation of each organ. However, waterlogging increased $\mathrm{N}$ distribution rate in stem and leaf, whereas grain $\mathrm{N}$ distribution rate decreased significantly after waterlogging. These results were in agreement with previous studies (Ren et al., 2014b; Phukan et al., 2016). Photosynthetic capacity of plant is closely associated with leaf $\mathrm{N}$ (Jiang et al., 2004). However, our results showed that waterlogging inhibited the accumulation of leaf $\mathrm{N}$ in maize, which would limit photosynthetic capacity, and thus decrease plant photosynthesis and dry-matter accumulation (Mu et al., 2016), ultimately resulting in the disruption of dry matter accumulation and translation in maize (Figure 2 and Table 3). The reduction in leaf nutrients induced by waterlogging lead to a reduction in "sink" characteristics and affected the normal "source" characteristics of photosynthetic and grain filling, resulting in a significant reduction in grain weight and yield (Ren et al., 2014a). Additionally, nitrogen harvest index (NHI) reflects $\mathrm{N}$ distribution in grain and vegetative organs at R6 stage (Jin et al., 2012). However, waterlogging decreases significantly grain $\mathrm{N}$ accumulation, resulting in the reduction of the NHI (Limami et al., 2014). Our study also showed waterlogging significantly decreased the NHI in maize, indicating that waterlogging significantly decreased grain $\mathrm{N}$ accumulation, and affected $\mathrm{N}$ use efficiency in maize. The most significant inhibition of NHI induced by waterlogging was observed at V3, followed by V6 and 10VT.

Waterlogging decreased leaf $\mathrm{N}$ accumulation, indicating that waterlogging inhibited $\mathrm{N}$ metabolism and assimilation, and disrupted crop physiological function. NR is one of key $\mathrm{N}$ metabolism enzymes, which controls the first step of $\mathrm{N}$ uptake and utilization, catalyzing the conversion of $\mathrm{NO}_{3}{ }^{-}$into $\mathrm{NO}_{2}{ }^{-}$, and is significantly positively related to corn production (Singletary et al., 1990). NR is also a photoinduced enzyme whose activity is easily affected by environmental factors such as light, temperature, and moisture (Tischner, 2000). Previous study (Phukan et al., 2016) has shown that waterlogging does lead to decrease of NR activity in plant leaves, resulting in a

TABLE 4 | Effects of waterlogging on grain yield and yield components of maize.

\begin{tabular}{|c|c|c|c|c|c|c|}
\hline Year & Hybrid & Treatment & Ear number & $\begin{array}{c}\text { Grain number } \\
\text { per grain }\end{array}$ & $\begin{array}{l}\text { 1000-grain } \\
\text { weight (g) }\end{array}$ & $\begin{array}{c}\text { Grain yield (kg } \\
\left.\mathrm{ha}^{-1}\right)\end{array}$ \\
\hline \multirow[t]{8}{*}{2012} & DH605 & V3-W & 61,714 & $438 c$ & $354 d$ & $9512 d$ \\
\hline & & V6-W & 61,822 & $459 d$ & $366 c$ & 10591c \\
\hline & & 10VT-W & 63,851 & $480 b$ & $373 b$ & $11437 b$ \\
\hline & & CK & 65,642 & $530 a$ & $403 a$ & $14018 a$ \\
\hline & ZD958 & V3-W & 61,192 & $453 d$ & $322 c$ & $9012 d$ \\
\hline & & V6-W & 62,100 & $481 c$ & $317 c$ & $9292 d$ \\
\hline & & 10VT-W & 63,367 & $543 b$ & $349 b$ & $12173 b$ \\
\hline & & CK & 66,250 & $573 a$ & $366 a$ & 13910a \\
\hline \multirow[t]{16}{*}{2013} & DH605 & V3-W & 65,421 & $395 d$ & $321 d$ & $8310 d$ \\
\hline & & V6-W & 65,607 & $453 c$ & $351 c$ & $10431 c$ \\
\hline & & 10VT-W & 65,590 & $495 b$ & $371 b$ & $12043 b$ \\
\hline & & CK & 65,607 & $556 a$ & $389 a$ & $14207 a$ \\
\hline & ZD958 & V3-W & 63,679 & $421 d$ & $273 d$ & $7314 d$ \\
\hline & & V6-W & 63,355 & $446 c$ & $294 c$ & $8312 c$ \\
\hline & & 10VT-W & 65,625 & $521 b$ & $321 b$ & $10999 b$ \\
\hline & & CK & 66,875 & $537 a$ & $345 a$ & $12388 a$ \\
\hline & ANOVA & & & & & \\
\hline & Year (Y) & & NS & NS & $* *$ & $*$ \\
\hline & Hybrid $(\mathrm{H})$ & & NS & NS & $* *$ & $*$ \\
\hline & Treatment $(\mathrm{T})$ & & $*$ & $*$ & $* *$ & $* *$ \\
\hline & $\mathrm{Y} \times \mathrm{H}$ & & NS & NS & $*$ & $*$ \\
\hline & $Y \times T$ & & NS & NS & NS & NS \\
\hline & $\mathrm{H} \times \mathrm{T}$ & & NS & NS & NS & NS \\
\hline & $\mathrm{Y} \times \mathrm{H} \times \mathrm{T}$ & & NS & NS & NS & NS \\
\hline
\end{tabular}

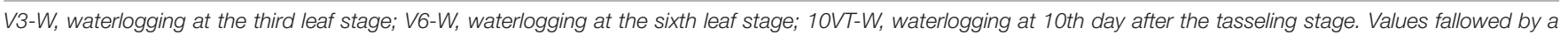

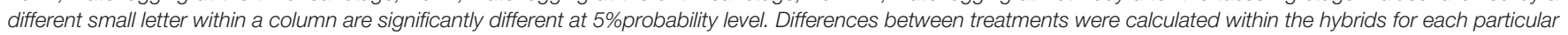
year. NS, Not significant. *Significant at the 0.05 probability level. ** Significant at the 0.01 probability level. 
significant reduction of $\mathrm{N}$ use efficiency. In our study, NR activity in maize was significantly decreased by waterlogging, indicating that waterlogging inhibited $\mathrm{N}$ metabolism, and disrupted $\mathrm{N}$ uptake and translation. The coupled GS-GOGAT reaction cycle is the main channel of $\mathrm{N}$ metabolism (Miflin and Habash, 2002). GS activity is significantly positively related to protein hydrolysis and the ability to adapt to abiotic stress (Dwivedi et al., 2012). Our study showed that GS and GOGAT activities declined significantly after waterlogging, leading to a significant drop in the activities of $\mathrm{N}$ metabolism enzymes and sugar metabolism enzymes in maize leaves, affecting the synthesis and transformation of amino acids (Limami et al., 2014), and ultimately inhibiting $\mathrm{N}$ metabolism, and disrupting $\mathrm{N}$ absorption and translation; thus, physiological processes associated with $\mathrm{N}$ became limited, resulting in a significant yield reduction of maize. GDH plays an important role in protein synthesis in the late grain-filling stage, and participated in the resynthesis of $\mathrm{NH}_{4}{ }^{+}$ under environmental stresses. The importance of GDH in the control of $\mathrm{N}$ assimilation and recycling of rice (Yamaya et al., 2002) and maize (Gallais and Hirel, 2004) has been established using physiological and quantitative genetic approaches; it is important in putative key reactions influencing grain yield and its components (Hirel et al., 2001; Dubois et al., 2003). Our study showed that waterlogging decreased GDH activity. This result indicated that waterlogging inhibited $\mathrm{N}$ assimilation and recycling, resulting in reduced grain yield. The NR, GS, GDH, and GOGAT activities of maize were significantly decreased after waterlogging, indicating that waterlogging inhibited leaf normal $\mathrm{N}$ metabolism, resulting in reduced $\mathrm{N}$ use efficiency, thus limiting normal physiological function associated with

\section{REFERENCES}

Ashraf, M., and Rehman, H. (1999). Mineral nutrient status of corn in relation to nitrate and long-term waterlogging. J. Plant Nutr. 22, 1253-1268. doi: 10.1080/ 01904169909365710

Aslam, M., Travis, R. L., and Rains, D. W. (2001). Enhancement of nitrate reductase activity and metabolic nitrate concentration by methionine sulfoximine in barley roots. Plant Sci. 161, 133-142. doi: 10.1016/S0168-9452(01)00396-X

Bailey-Serres, J., Fukao, T., Gibbs, D. J., Holdsworth, M. J., Lee, S. C., Licausi, F., et al. (2012). Making sense of low oxygen sensing. Trends Plant Sci. 17, 129-138. doi: 10.1016/j.tplants.2011.12.004

Chi, M. Z., and Zhou, B. S. (2006). Research advance in physiological damage of flooding and waterlogging resistance. J. Anhui Agric. Sci. 34, 209-210.

Debouba, M., Gouia, H., Suzuki, A., and Ghorbel, M. H. (2006). NaCl stress effects on enzymes involved in nitrogen assimilation pathway in tomato 'Lycopersicon esculentum' seedlings. J. Plant Physiol. 163, 1247-1258. doi: 10.1016/j.jplph. 2005.09.012

Dubois, F., Tercé-Laforgue, T., Gonzalez-Moro, M. B., Estavillo, J. M., Sangwan, R., Gallais, A., et al. (2003). Glutamate dehydrogenase in plants: is there a new story for an old enzyme? Plant Physiol. Biochem. 41, 565-576. doi: 10.1016/S09819428(03)00075-5

Dwivedi, S. K., Singh, V. P., Singh, G. P., and Arora, A. (2012). Combined effect of cytokinin, paclobutrazol and ascorbic acidon nitrogen metabolism and yield of wheat (Triticumaestivum L.) under water deficit stress condition. Indian J. Plant Physiol. 17, 259-267.

Eva, S. R., Marla, M. R. W., Rlos, J. J., Blasco, B., Rosales, M., Melgarejo, R., et al. (2011). Ammonia production and assimilation: its importance as a tolerance mechanism during moderate water deficit in tomato plants. J. Plant Physiol. 168, 816-823. doi: 10.1016/j.jplph.2010.11.018
N. N metabolism was most susceptible to damage when waterlogging occurred at the V3 stage, followed by V6 and 10VT stages.

\section{CONCLUSION}

Waterlogging decreased the activity of key $\mathrm{N}$ metabolism enzymes (nitrate reductase, glutamine, GOGAT, and GDH), resulting in the inhibition of leaf normal $\mathrm{N}$ metabolism. Waterlogging also hindered $\mathrm{N}$ accumulation and translation, and reduced maize yield. The V3 stage was most susceptible to waterlogging, followed by V6 and 10VT stages.

\section{AUTHOR CONTRIBUTIONS}

JZ and BR initiated and designed the research. BR performed the experiments, analyzed the data, and wrote the manuscript. JZ, SD, $\mathrm{PL}$, and BZ revised and edited the manuscript and also provided advice on the experiments.

\section{ACKNOWLEDGMENTS}

We are grateful for grants from National Modern Agricultural Technology \& Industry System (CARS-02-20), National Basic Research Program of China (973, Program: 2015CB150404), and Shandong Province Key Agricultural Project for Application Technology Innovation.

Gallais, A., and Hirel, B. (2004). An approach of the genetics of nitrogen use efficiency in maize. J. Exp. Bot. 396, 295-306. doi: 10.1093/jxb/erh006

Hibbard, P. L. (2002). Notes on the determination of nitrogen by the kjeldahl method. Ind. Eng. Chem. 2, 463-466. doi: 10.1021/ie50023a010

Hirel, B., Bertin, P., Quilleré, I., Bourdoncle, W., Attagnant, C., Dellay, C., et al. (2001). Towards a better understanding of the genetic and physiological basis for nitrogen use efficiency in maize. Plant Physiol. 125, 1258-1270. doi: 10.1104/ pp.125.3.1258

Hoff, T., Stummann, B. M., and Henningsen, K. W. (1992). Structure function and regulation of nitrate reductase in higher plants. Physiol. Plant. 84, 616-624. doi: 10.1111/j.1399-3054.1992.tb04712.x

Iqra, A., and Naveela, N. (2013). Effect of waterlogging and drought stress in plants. Int. Water Resour. Environ. Sci. 2, 34-40.

Jackson, M. B., and Campbell, D. J. (2006). Effect of benzyladenine and gibberellic acid on the responses of tomato plants to anaerobic root environments and to ethylene. New Phytol. 82, 331-340. doi: 10.1111/j.1469-8137.1979.tb02658.x

Jiang, D., Dai, T., Jing, Q., Cao, W., Zhou, Q., Zhao, H., et al. (2004). Effects of long-term fertilization on leaf photosynthetic characteristics and grain yield in winter wheat. Photosynthetica 42, 439-446. doi: 10.1023/B:PHOT.0000046164. 77410.ef

Jin, L. B., Cui, H. Y., Li, B., Zhang, J. W., Dong, S. T., and Liu, P. (2012). Effects of integrated agronomic management practices on yield and nitrogen efficiency of summer maize in North China. Field Crops Res. 134, 30-35. doi: 10.1016/j.fcr. 2012.04.008

Kaiser, W. M., and Huber, S. C. (1994). Posttranslational regulation of nitrate reductase in higher plants. Plant Physiol. 106, 817-821. doi: 10.1104/pp.106. 3.817

Kozlowski, T. T. (1997). Responses of woody plants to flooding and salinity. Tree Physiol. 17, 490. doi: 10.1111/j.1438-8677.2012.00597.x 
Krouk, G., Crawford, N. M., Coruzzi, G. M., and Tsay, Y. F. (2010). Nitrate signaling: adaptation to fluctuating environments. Curr. Opin. Plant Biol. 13, 266-273. doi: 10.1016/j.pbi.2009.12.003

Lawlor, D. W. (2002). Carbon and nitrogen assimilation in relation to yield: mechanisms are the key to understanding production systems. J. Exp. Bot. 53, 773-787. doi: 10.1093/jxb/53.370.773

Limami, A. M., Diab, H., and Lothier, J. (2014). Nitrogen metabolism in plants under low oxygen stress. Planta 239, 531-541. doi: 10.1007/s00425-0132015-9

Lin, C. C., and Kao, C. H. (1996). Distributed ammonium assimilation is associated with growth inhibition of roots in rice seedlings caused by $\mathrm{NaCl}$. Plant Growth Regul. 18, 233-238. doi: 10.1007/BF00024387

Miflin, B. J., and Habash, D. Z. (2002). The role of glutamine synthetase and glutamate dehydrogenase in nitrogen assimilation and possibilities for improvement in the nitrogen utilization of crops. J. Exp. Bot. 53, 979-987. doi: $10.1093 /$ jexbot/53.370.979

Milroy, S. P., Bange, M. P., and Thongbai, P. (2009). Cotton leaf nutrient concentrations in response to waterlogging under field conditions. Field Crops Res. 113, 246-255. doi: 10.1016/j.fcr.2009.05.012

Mohanty, B., and Fletcher, J. S. (1980). Ammonium influence on nitrogen assimilating enzymes and protein accumulation in suspension cultures of Paul's scarlet rose. Physiol. Plant. 48, 453-459. doi: 10.1111/j.1399-3054.1980. tb03285.x

Monreal, J. A., Jiménez, E. T., Remesal, E., Morillo-Velarde, R., GarclaMauri, O. S., and Echevarrla, C. (2007). Proline content of sugar beet storage roots: response to water deficit and nitrogen fertilization at field conditions. Environ. Exp. Bot. 60, 257-267. doi: 10.1016/j.envexpbot.2006. 11.002

Mu, X. H., Chen, Q. W., Chen, F. J., Yuan, L. X., and Mi, G. H. (2016). Within-leaf nitrogen allocation in adaptation to low nitrogen supply in maize during grain-filling stage. Front. Plant Sci. 7:699. doi: 10.3389/fpls.2016. 00699

Phukan, U. J., Mishra, S., and Shukla, R. K. (2016). Waterlogging and submergence stress: affects and acclimation. Crit. Rev. Biotechnol. 36, 956-966. doi: 10.3109/ 07388551.2015.1064856

Przywara, G., and Stcdaniewski, W. (1999). The influence of waterlogging at different temperatures on penetration depth and porosity of roots and on stomatal diffusive resistance of pea and maize seedlings. Acta Physiol. Plant. 21, 405-411. doi: 10.1007/s11738-999-0013-0

Ramanjulu, S., and Sudhakar, C. (1997). Drought tolerance is partly related to amino acid accumulation and ammonia assimilation: a comparative study in two mulberry genotypes differing in drought sensitivity. J. Plant Physiol. 150, 345-350. doi: 10.1016/S0176-1617(97)80131-9

Ren, B. Z., Zhang, J. W., Dong, S. T., Liu, P., and Zhao, B. (2016). Root and shoot responses of summer maize to waterlogging at different stages. Agron. J. 108, 1060-1069. doi: 10.2134/agronj2015.0547
Ren, B. Z., Zhang, J. W., Li, X., Fan, X., Dong, S. T., Liu, P., et al. (2014a). Effects of waterlogging on the yield and growth of summer maize under field conditions. Can. J. Crop Sci. 94, 23-31. doi: 10.4141/cjps2013-175

Ren, B. Z., Zhang, J. W., Li, X., Fan, X., Dong, S. T., Liu, P., et al. (2014b). Effect of waterlogging on nutrient uptake and transport of summer maize. J. Plant Nutr. Fertilizer 20, 298-308.

Ritchie, S. W., and Hanway, J. J. (1982). How a Corn Plant Develops. Special Report, No. 48. Ames, IA: Iowa State University.

Robredo, A., Usue, P. L., Jon, M. A., Lacuesta, M., Amaia, M. P., and Alberto, M. R. (2011). Elevated CO2 reduces the drought effect on nitrogen metabolism in barley plants during drought and subsequent recovery. Environ. Exp. Bot. 71, 399-408. doi: 10.1016/j.envexpbot.2011.02.011

Sergey, S. (2011). Physiological and cellular aspects of phytotoxicity tolerance in plants: the role of membrane transporters and implications for crop breeding for waterlogging tolerance. New Phytol. 190, 289-298. doi: 10.1111/j.1469-8137. 2010.03575.x

Singh, R. P., and Srivastava, H. S. (1986). Increase in glutamate synthase (n.d.) activity in maize seedlings in response to nitrate and ammonium nitrogen. Physiol. Plant. 66, 413-416. doi: 10.1111/j.1399-3054.1986. tb05944.x

Singletary, G. W., Doehlert, D. C., Wilson, C. M., Muhitch, M. J., and Below, F. E. (1990). Response of enzymes and storage proteins of maize endosperm to nitrogen supply. Plant Physiol. 94, 858-864. doi: 10.1104/pp.94.3.858

Stitt, M., Müller, C., Matt, P., Gibon, Y., Carillo, P., Morcuende, R., et al. (2002). Steps towards an integrated view of nitrogen metabolism. J. Exp. Bot. 53, 959-970. doi: 10.1093/jexbot/53.370.959

Sung, F. J. M., and Sun, Y. W. (1990). Seasonal patterns of nitrate reductase and nitrogenase activities in Arachis hypogaea. Field Crops Res. 25, 215-222. doi: 10.1016/0378-4290(90)90004-U

Tischner, R. (2000). Nitrate uptake and reduction in higher and lower plants. Plant Cell Environ. 23, 1015-1024. doi: 10.1046/j.1365-3040.2000.00595.x

Yamaya, T., Obara, M., Nakajima, H., Sasaki, S., Hayakawa, T., and Sato, T. (2002). Gentic manipulation and quantitative-trait loci mapping for nitrogen recycling in rice. J. Exp. Bot. 370, 917-925. doi: 10.1093/jexbot/53. 370.917

Conflict of Interest Statement: The authors declare that the research was conducted in the absence of any commercial or financial relationships that could be construed as a potential conflict of interest.

Copyright (C) 2017 Ren, Dong, Zhao, Liu and Zhang. This is an open-access article distributed under the terms of the Creative Commons Attribution License (CC BY). The use, distribution or reproduction in other forums is permitted, provided the original author(s) or licensor are credited and that the original publication in this journal is cited, in accordance with accepted academic practice. No use, distribution or reproduction is permitted which does not comply with these terms. 